DOI: https://doi.org/10.33330/jurteksi.v6i1.403

Available online at http://jurnal.stmikroyal.ac.id/index.php/jurteksi

\title{
PAYROLL INFORMATION SYSTEM AT PT. ASTRO NIAGA JAYA (SIPESTRO)
}

\author{
Dinda Ayu Muthia ${ }^{1 *}$ Anip Budi Setiawan ${ }^{1,}$, Waliyyuddin ${ }^{1,}$, Muhammad \\ Syahrul Gunawan ${ }^{1}$ \\ Sistem Informasi, Universitas Bina Sarana Informatika \\ email: dinda.dam@bsi.ac.id
}

\begin{abstract}
Payroll is an acceptance in return from the employer to the employee for a job or service that has been done and is expressed or valued in the form of money determined on the basis of an agreement or legislation and is paid on the basis of an employment agreement between the employer and the employee including benefits, both for the employees themselves and for the family. This research takes place at PT. Astro Niaga Jaya. The payroll process at PT. Astro Niaga Jaya is still conventional. Salary calculations are based on different details that hinder the performance process of the human resources department. Errors in calculating salaries can be fatal because it will affect the preparation of financial statements. Therefore, it is necessary to have an employee payroll information system so that the human resources department is not wrong in collecting employee payroll data. The purpose of this paper is to design employee attendance and payroll information systems at PT. Astro Niaga Jaya using Waterfall method in order to produce information that is fast, precise and accurate. The Waterfall method is often used in designing an information system. Payroll Information System can work effectively and efficiently.
\end{abstract}

Keywords: payroll, information, system

\begin{abstract}
Abstrak: Penggajian adalah suatu penerimaan sebagai imbalan dari pengusaha kepada karyawan untuk suatu pekerjaan atau jasa yang telah dilakukan dan dinyatakan atau dinilai dalam bentuk uang yang ditetapkan atas dasar persetujuan atau peraturan perundang-undangan serta dibayarkan atas dasar suatu perjanjian kerja antara pengusaha dengan karyawan termasuk tunjangan, baik untuk karyawan itu sendiri maupun untuk keluarga. Penelitian ini berlangsung di PT. Astro Niaga Jaya. Proses penggajian di PT. Astro Niaga Jaya masih konvensional. Perhitungan gaji didasarkan pada berbagai rincian yang berbeda-beda yang menghambat proses kinerja departemen sumber daya manusia. Kesalahan dalam menghitung gaji bisa berakibat fatal karena akan mempengaruhi penyusunan laporan keuangan. Oleh karena itu, perlu adanya sistem informasi penggajian karyawan agar departemen sumber daya manusia tidak salah dalam mengumpulkan data penggajian karyawan. Tujuan penulisan ini adalah untuk merancang sistem informasi absensi kehadiran dan penggajian karyawan di PT. Astro Niaga Jaya menggunakan metode Waterfall untuk menghasilkan informasi yang cepat, tepat dan akurat. Metode Waterfall sering digunakan dalam merancang sistem informasi. Sistem Informasi Penggajian dapat bekerja secara efektif dan efisien.
\end{abstract}

Kata kunci: penggajian, informasi, sistem 
DOI: https://doi.org/10.33330/jurteksi.v6i1.403

Available online at http://jurnal.stmikroyal.ac.id/index.php/jurteksi

\section{INTRODUCTION}

Payroll is an acceptance in return from the employer to the employee for a job or service that has been done and is expressed or valued in the form of money determined on the basis of an agreement or legislation and is paid on the basis of an employment agreement between the employer and the employee including benefits, both for the employees themselves and for the family [1].

Human Resources

Management plays a very important role in improving the performance of employees of an organization, both profit oriented and nonprofit organizations. Management's inability to manage its human resources can cause disharmony in relations between employees and the organization's management. If this continues without good handling, the work motivation of the employees will decrease, so that it can affect the performance of the organization [2].

This research takes place at PT. Astro Niaga Jaya. The payroll process at PT. Astro Niaga Jaya is still conventional. Salary calculations are based on different details that hinder the performance process of the human resources department. Errors in calculating salaries can be fatal because it will affect the preparation of financial statements. Therefore, it is necessary to have an employee payroll information system so that the human resources department is not wrong in collecting employee payroll data.

The Waterfall method is often used in designing an information system. Related research that uses the waterfall method includes the design of employee payroll information systems on PR. Tunas Mandiri Pacitan Regency [3], employee payroll application at Surabaya Surgical Hospital [4], and Android-based assistant lecturer attendance application [5].

The purpose of this paper is to design employee attendance and payroll information systems at PT. Astro Niaga Jaya using Waterfall method in order to produce information that is fast, precise and accurate.

The benefits of this research are as a material for evaluating the current system and produce an information system that is fast and accurate in helping attendance and payroll process.

\section{A. Information System \\ Information system is a system} in organizations that bring together daily transaction processing needs, support operations, managerial and strategic activities of an organization and provide certain outside parties with the necessary reports [6].

B. Database

A database is a coherent collection of data, typically describing the activities of one or more related organization. It is built and implemented with data for a specific purpose. It has a group of user who can access, modify and update the database [7].

\section{Entity Relationship Diagram}

Entity relationship diagram is a pictorial representation of data items and their relationship. It is 
representing the schemas rather than the instances and so it is a logical design of databases where a data items, constraints and their relationship are defined [7].

D. Waterfall Model

The waterfall model is often called a linear sequential model that is the sequential software life-flow approach starting from analysis, design, coding, testing and supporting or maintenance stages [8].

Five stages of waterfall model [9] can be seen in Fig. 1.

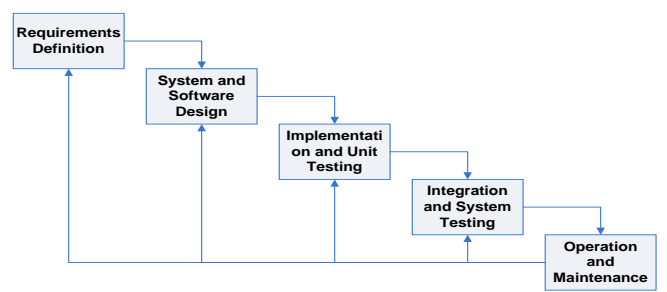

Fig. 1. The Waterfall Model

\section{E. Unified Modelling Language (UML)}

UML is one of the language standards that is widely used in the industrial world to define requirements, make analysis and design, and describe architecture in object oriented programming [10].

1. Use Case Diagram

Use Case Diagram illustrates the main function of a system. It is drawn to gather and define system's requirements [11].

2. Activity Diagram

Activity Diagram can be defined as a diagram that models the behaviour in a business process [11]. This diagram shows the workflow or activities of an existing system or business process [12].
F. Black-box Testing

Black-box testing is the most used testing to ensure classes correctness. It is used because each class represents an encapsulated object [11].

\section{METHOD}

In this research, three stages of waterfall model had been done. The detail explanation of each stages include:

1. Requirements Definition

This stage is carried out to describe the user's needs into a system design which will then be made into a web-based information system.

2. System and Software Design

Design a computerized payroll system and explain in the form of Unified Modeling Langueage (UML). Relationships between entities that exist in the proposed system are described in the form of Entity Relationship Diagrams (ERD).

3. Implementation and Unit Testing Conduct unit tests on payroll applications that have been made. Black-box testing is tested on all input views of the application.

\section{RESULTS AND DISCUSSION}

A. Functional Requirements

In the payroll application there are two users who can interact with each other in the system environment, namely: Employees, and Finance Staff. Both users have different 
DOI: https://doi.org/10.33330/jurteksi.v6i1.403

Available online at http://jurnal.stmikroyal.ac.id/index.php/jurteksi

interaction characteristics with the system and have different information needs, such as the following:

1. Finance Staff's needs:
a. Managing job data.
b. Managing allowances types
c. Managing employee data
d. Managing position allowances
e. Managing employee attendance data
f. Managing salary receipt
g. Managing attendance reports
h. Managing salary reports
i. Changing password

2. Employee's needs:

a. Employee can input attendance data

b. Employee can view attendance history

c. Employee can change password

B. Database Design

Entity relationship diagram had been illustrated in Fig. 2. Logical record structure can be seen in Fig. 3 .

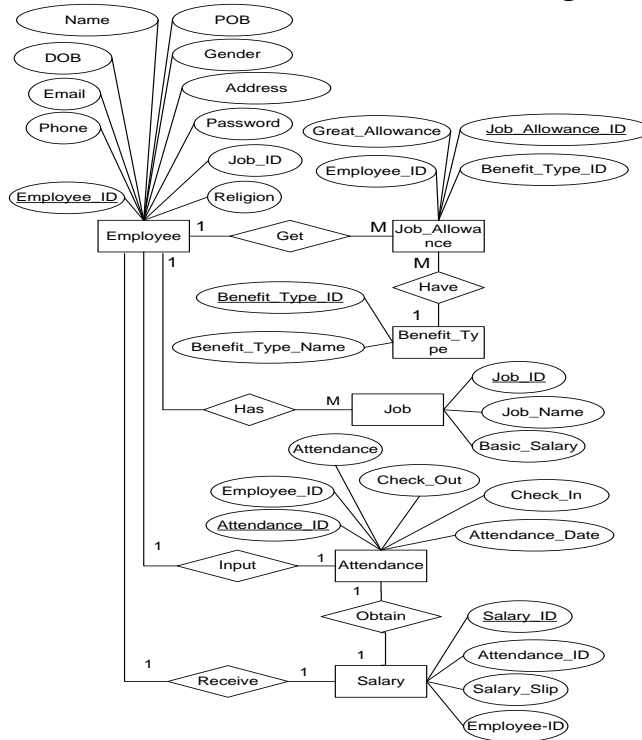

Fig. 2. Entity Relationship Diagram

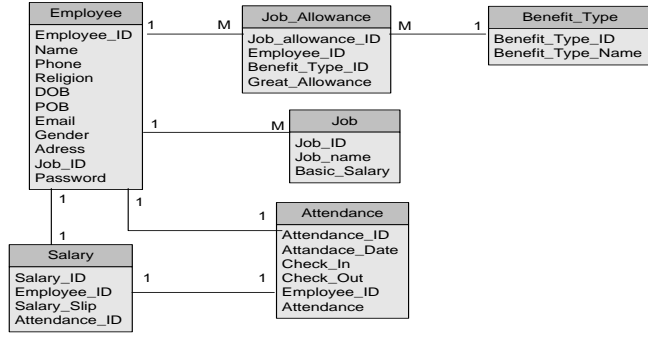

Fig. 3. Logical Record Structure

C. Use Case Diagram

Use case diagram of proposed system can be seen in Fig. 4.

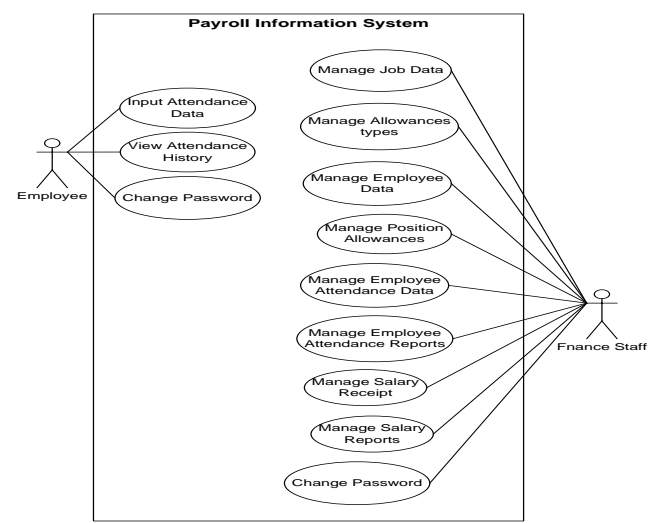

Fig. 4. Use Case Diagram

D. Activity Diagram

Activity diagram of proposed system can be seen in Fig. 5. This diagram is made based on "Input attendance data" use case.

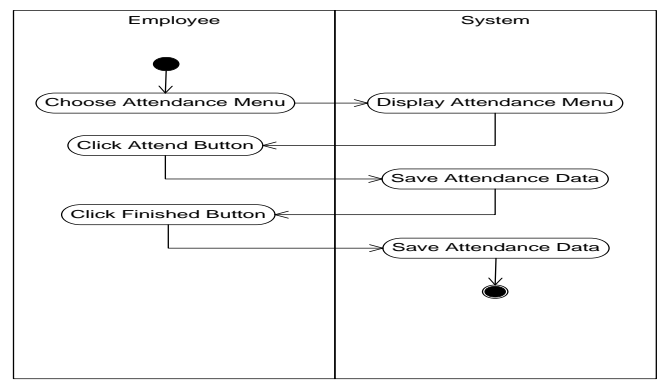

Fig. 5. Activity Diagram

E. Implementation

The proposed system's implementation can be seen in Fig. 6, 7 , and 8 . 
ISSN 2407-1811 (Print)

ISSN 2550-0201 (Online)
JURTEKSI (Jurnal Teknologi dan Sistem Informasi)

Vol. VI No. 1, Des 2019, hlm. 59 - 64

DOI: https://doi.org/10.33330/jurteksi.v6i1.403

Available online at http://jurnal.stmikroyal.ac.id/index.php/jurteksi

Fig. 6. Main Menu Page

Fig. 7. Employee Data's Page
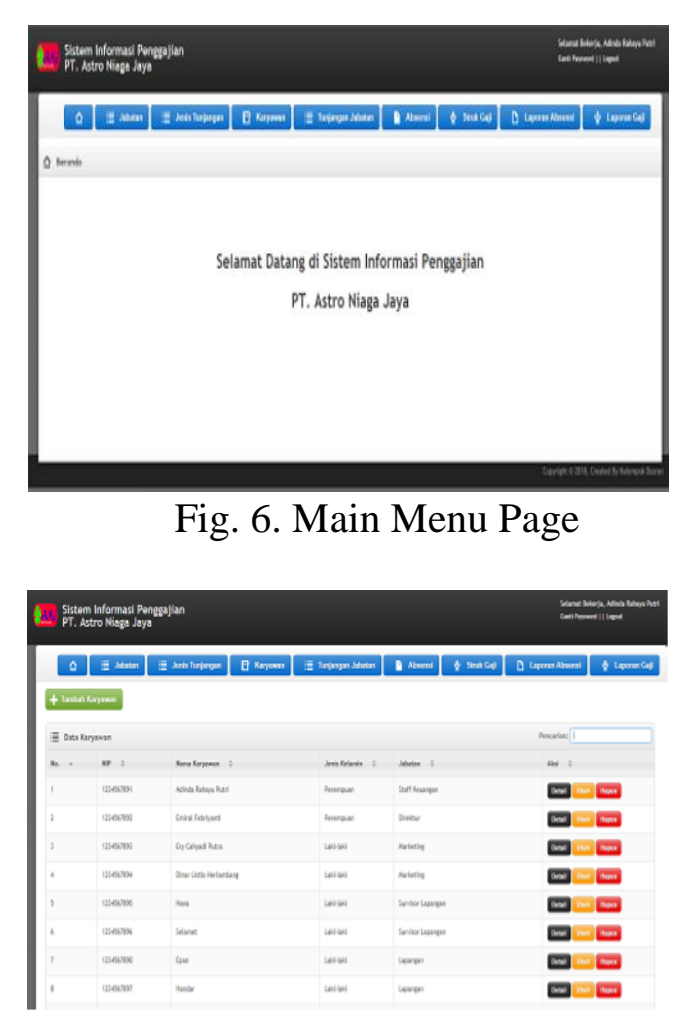

Table 1. Black-box testing on employee's log in page

\begin{tabular}{|c|c|c|c|c|c|}
\hline No & Testing scenario & Test case & Expected results & Result & Conclusion \\
\hline 1. & $\begin{array}{l}\text { ID and Password } \\
\text { are not filled then } \\
\text { click the login } \\
\text { button }\end{array}$ & $\begin{array}{l}\text { ID (empty) } \\
\text { Password } \\
\text { (empty) }\end{array}$ & $\begin{array}{l}\text { The system will deny } \\
\text { user access and display } \\
\text { "Please Fill ID and } \\
\text { Password" }\end{array}$ & $\begin{array}{l}\text { Compatible } \\
\text { to } \\
\text { expectations }\end{array}$ & Valid \\
\hline 2. & $\begin{array}{l}\text { ID is filled in and } \\
\text { the Password is } \\
\text { not filled in or } \\
\text { blank then click } \\
\text { the log in button }\end{array}$ & $\begin{array}{l}\text { ID: } \\
\text { 1232252336 } \\
\text { Password } \\
\text { (empty) }\end{array}$ & $\begin{array}{l}\text { The system will deny } \\
\text { user access and display } \\
\text { "The Data is } \\
\text { Incomplete" }\end{array}$ & $\begin{array}{l}\text { Compatible } \\
\text { to } \\
\text { expectations }\end{array}$ & Valid \\
\hline 3. & $\begin{array}{l}\text { Fill in one of the } \\
\text { wrong conditions } \\
\text { in the ID or } \\
\text { Password then } \\
\text { click the login } \\
\text { button }\end{array}$ & $\begin{array}{l}\text { ID: } \\
\text { 1232252336 } \\
\text { (Correct Data) } \\
\text { Password: } \\
999999 \\
\text { (Incorrect } \\
\text { Data) } \\
\end{array}$ & $\begin{array}{l}\text { The system will deny } \\
\text { user access and display } \\
\text { "ID or Password is } \\
\text { Incorrect" }\end{array}$ & $\begin{array}{l}\text { Compatible } \\
\text { to } \\
\text { expectations }\end{array}$ & Valid \\
\hline 4. & $\begin{array}{l}\text { Fill in the ID and } \\
\text { Password with the } \\
\text { correct data then } \\
\text { click the login } \\
\text { button }\end{array}$ & $\begin{array}{l}\text { ID: } \\
\text { 1232252336 } \\
\text { (Correct Data) } \\
\text { Password: } \\
999999 \\
\text { (Correct Data) } \\
\end{array}$ & $\begin{array}{l}\text { The system accepts } \\
\text { login access and } \\
\text { displays "successful } \\
\text { login" then immediately } \\
\text { displays user info }\end{array}$ & $\begin{array}{l}\text { Compatible } \\
\text { to } \\
\text { expectations }\end{array}$ & Valid \\
\hline
\end{tabular}

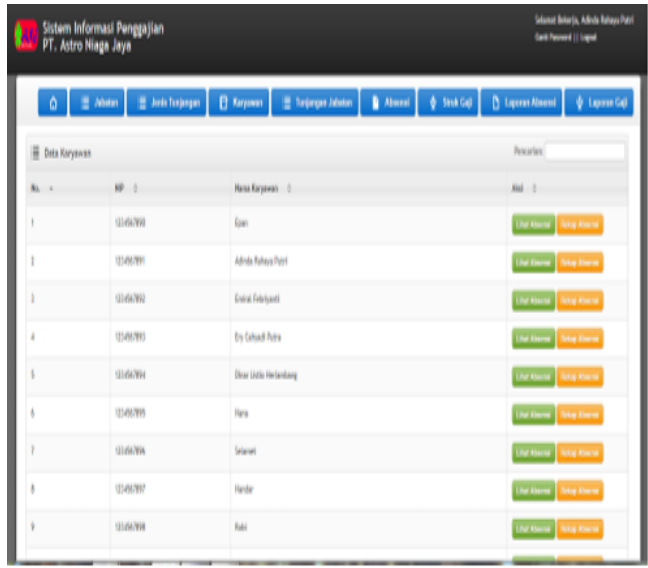

Fig. 8. Employee's Attendance Data

\section{F. Black-box Testing}

Table 1 describes black-box testing process of employee's log in page. 
DOI: https://doi.org/10.33330/jurteksi.v6i1.403

Available online at http://jurnal.stmikroyal.ac.id/index.php/jurteksi

\section{CONCLUSION}

Based on the previous discussion, it can be concluded that:

1. Payroll Information Systems can simplify the processing of attendance data and salary calculation.

2. Information generated by the system is fast and accurate.

3. Data loss and damage can be avoided.

\section{DAFTAR PUSTAKA}

[1] S. Sumarsono, Ekonomi Manajemen Sumber Daya Manusia dan Ketenagakerjaan. Yogyakarta: Graha Ilmu, 2003.

[2] M. Tofik, Panduan Praktis Membuat Aplikasi Penggajian dengan Excel 2007. Jakarta: mediakita, 2010.

[3] D. Lestari, "Perancangan Sistem Informasi Penggajian Karyawan Pada PR. Tunas Mandiri Kabupaten Pacitan," Indones. J. Netw. Secur., vol. 3, no. 4, pp. 22-26, 2014.

[4] L. A. Sanjani, S. J. Hartati, and P. Sudarmaningtyas, "Rancang Bangun Sistem Informasi Penggajian Pegawai dan Remunerasi Jasa Medis Pada Rumah Sakit Bedah Surabaya," J. Sist. Inf., vol. 3, no. 1, 2014.

[5] T. M. Nuddin and D. L. Fithri, "Sistem Absensi Asisten Dosen Menggunakan QR Code Scanner Berbasis Android Pada Program Studi Sistem Informasi Universitas Muria Kudus," Pros. SNATI, no. 2, pp. 303-
$310,2015$.

[6] J. H. Mustakini, Analisis dan Desain Sistem Informasi. Yogyakarta: Andi, 2005.

[7] A. K. Gupta, Taxonomy of Database Management System. New Delhi: Firewall Media, 2007.

[8] A. Nugraha and A. Octasia, "Sistem Informasi Penjualan Kaos Berbasis Web Pada Distro Sickness Berbasis ECommerce," Semin. Nas. Ilmu Pengetah. dan Teknol. Komput. Nusa Mandiri, pp. 299-302, 2016.

[9] I. Sommerville, Software Engineering Ninth Edition. Pearson Education, Inc, 2011.

[10] E. W. Fridayanthie and T. Mahdiati, "Rancang Bangun Sistem Informasi Permintaan ATK Berbasis Intranet (Studi Kasus: Kejaksaan Negeri Rangkasbitung)," J. Khatulistiwa Inform., vol. IV, no. 2, pp. 126-138, 2016.

[11] D. A. Muthia, A. Ramadhani, A. Kurniawan, and R. Irfansyah, "Online Student Admission Application at SMK Al-Basyariah Bojong Gede," $J$. Sink., vol. 3, no. 2, pp. 1-6, 2019.

[12] A. Oktaviani, D. A. Muthia, M. Susanti, and F. P. Sujatmiko, "Perancangan Program Penilaian Peserta Pusdiklat Pada BPSDM Kemendagri Jakarta," J. Sink., vol. 3, no. 1, 2019. 